\title{
Should Euthanasia be legalised in England and Wales? Interpreting John Stuart Mill’s Harm Principle
}

\author{
Lauren Wharton, Northumbria University, $4^{\text {th }}$ Year MLaw
}

\section{Introduction}

In September 2017, Margaret Somerville wrote a powerful article in The Guardian arguing that euthanasia offered individuals death rather than loving care. ${ }^{1}$ She cautioned against normalising assisted dying and the unavoidable "slippery slope". 2 This article will explore the arguments put forward in Somerville's piece, against John Stuart Mill's harm principle. The author will argue that the harm principle is preferred for the following reasons; an individual's autonomy is central to a liberal society, individuals should also be free to make their own choices about their life, and the law should be equal to all. The article will look at criticisms and support for the harm principle and will finally reach a conclusion on whether or not assisted suicide and euthanasia should be legalised.

\section{The harm principle}

The boundary between individual freedom and state intervention has always been a hard one to place. John Stuart Mill was a very influential theorist on liberalism in the $19^{\text {th }}$ century. His harm principle still remains influential on public debate including arguments involving euthanasia and assisted suicide as it is seen as an argument for liberty. ${ }^{3}$ The harm principle states 'the only purpose for which power can be rightfully exercised over any member of a civilised community, against his will, is to prevent harm to others. His own good, either physical or moral, is not such a warrant.' ${ }^{4}$ At the heart of the harm principle is the concern for individual liberty and toleration. This is

\footnotetext{
${ }^{1}$ Margaret Somerville 'Legalising assisted dying would be a failure of collective human memory and imagination', The Guardian (2017) <https://www.theguardian.com/commentisfree/2017/sep/20/legalising-assisted-dying-wouldbe-a-failure-of-collective-human-memory-and-imagination> accessed 21 March 2018 ${ }^{2}$ Ibid.

${ }^{3}$ Steven D Smith 'Is the harm principle illiberal' (2006) 51 American Journal of Jurisprudence, 25

${ }^{4}$ John Stuart Mill, On Liberty (2 ${ }^{\text {nd }}$ edn, London: John W Parker \& Son West Strand 1859) 22
} 
why it is suited to reflect the liberal attitudes of some citizens and policy makers towards the treatment of an individual. ${ }^{5}$

According to Mill liberty means that individuals are free to set their own course of life to suit their own characteristics. We should be free to do as we wish without judgement from others even if they disagree with our choices. As long as we do not cause them harm we should be free to live life as we wish. ${ }^{6}$ It is the autonomy of the individual that Mill believed is central to liberty. The harm principle aims to restrict the intervention by the state and society in an individual's private life. ${ }^{7}$

Mill did recognise that there will be state imposed restrictions and that is part of society. However these restraints are only justified if they are to promote individual autonomy. ${ }^{8}$ 'What is right in politics is not the will of the people but the good of the people.' ${ }^{9}$ The role of the government in the eyes of Mill is to promote an individual's capacity to remain autonomous. ${ }^{10}$ In the next section, this article will elaborate on why the current law regarding assisted suicide and euthanasia in the UK infringes a persons autonomy and how the premises of the decision is not for the law but for the individual who wants to seek assisted suicide or euthanasia.

\section{The article and the harm principle}

'Euthanasia is the act of deliberately ending a person's life to relieve suffering' ${ }^{\text {,11 }}$ and assisted suicide is 'the act of deliberately assisting or encouraging another person to kill themselves., ${ }^{12}$ In the UK assisted suicide and euthanasia are illegal. Euthanasia falls into the category of murder or manslaughter and can result in a maximum penalty of life imprisonment. ${ }^{13}$ Under the Suicide Act of 1961 assisting or encouraging someone to commit suicide can result in a 14 years prison sentence. ${ }^{14}$ However killing or trying

\footnotetext{
${ }^{5}$ Nils Holtug 'The Harm Principle' (2002) 5(4) Ethical Theory and Moral Practice, 357

${ }^{6}$ John Stuart Mill, On Liberty ( $2^{\text {nd }}$ edn, London: John W Parker \& Son West Strand 1859) 2627

${ }^{7}$ Ben Saunders ‘Reformulating Mill’s Harm Principle’ (2016) 125(500) Mind

${ }^{8}$ John Stuart Mill, On Liberty ( $2^{\text {nd }}$ edn, London: John W Parker \& Son West Strand 1859)

${ }^{9}$ Richard Reeves John Stuart Mill: a Victorian Firebrand (Atlantic Books 2007)

${ }^{10}$ John Stuart Mill, On Liberty ( $2^{\text {nd }}$ edn, London: John W Parker \& Son West Strand 1859)

11 National Health Service 'Euthanasia and assisted suicide', NHS Choices $<$ https://www.nhs.uk/conditions/euthanasia-and-assisted-suicide/> accessed $28^{\text {th }}$ March 2018

12 Ibid

${ }^{13}$ Op cit, n. 11

14 The Suicide Act 1961, s.1.
} 
to kill yourself is not illegal. In recent years there has been much debate as to whether assisted suicide and euthanasia should be considered a crime.

When questioning whether or not euthanasia and assisted suicide should be legalised it is not easy to come across the answer. Many have conflicting opinions regarding this matter. In her article in The Guardian, Somerville is strongly against legalising euthanasia and assisted suicide. She states that euthanasia proponents only look at the individual and the discussion is based around the present society. Those against euthanasia, according to Somerville, do not just look at the individual's wants and needs but the future implications and protection of the 'common good'.${ }^{15}$ Legalising assisted suicide and euthanasia would, Somerville's view, 'sanction a view of autonomy holding that individuals may, in the name of their own private, idiosyncratic view of the good life, call upon others, including such institutions as medicine, to help them pursue that life, even at the risk of harm to the common good'. ${ }^{16}$ This view would seem to support the harm principle in indicating that deciding what is good in a person's private life is the individual's choice and has little concern for the overall societal consequences which result from this self-governance. ${ }^{17}$

The harm principle aims to defend self-governance; freedom means an individual should be allowed to pursue their own good in their own way. This includes different experiments of living and as long as you do not cause harm to someone else you can pursue your own vision of what is good even if others oppose it. ${ }^{18}$ 'If resistance waits till life is reduced to nearly one uniform type, all deviations from that type will come to be considered impious, immoral and even monstrous and contrary to nature. ${ }^{19}$ Despite Somerville's article arguing the illegality of euthanasia is for the common good, it is clear that if you look at this from a Millsian liberalistic view, there are different interpretations of what is good and to limit this to one type is to deem all

\footnotetext{
${ }^{15}$ Margaret Somerville 'Legalising assisted dying would be a failure of collective human memory and imagination', The Guardian (2017) $<$ https://www.theguardian.com/commentisfree/2017/sep/20/legalising-assisted-dying-wouldbe-a-failure-of-collective-human-memory-and-imagination> accessed 21 March 2018 ${ }_{16}$ Daniel Callahan 'When Self Determination Runs Amok' Hastings Center Report (March/April 1992), 52

${ }^{17}$ Mary Donnelly and Claire Murray, Ethical and legal debates in Irish healthcare (Manchester University Press 2016) 60

${ }^{18}$ John Stuart Mill, On Liberty ( $2^{\text {nd }}$ edn, London: John W Parker \& Son West Strand 1859)

${ }^{19}$ Ibid page 113
} 
deviations immoral. It would be unfair to those who deviate from the norm to be punished for it. $^{20}$

Somerville's article also addresses her concerns about how the ethical tones of society can be perceived if euthanasia is legalised. She states that euthanasia is offering the weak and most in need 'death instead of loving care.' ${ }^{21}$ However Mill's harm principle provides that it is paramount that the individual is given a choice. If someone finds them self in a situation that causes risk to their life the state can intervene to offer support although it is crucial that they do not override an individual's autonomy if they refuse to accept help. ${ }^{22}$ The support is there if an individual wants to take it, there is still the option of care, but fundamentally that option lies with the individual. If the state were to legalise euthanasia it does not show the state supporting suicide, it is stating assisted suicide falls in the realm of personal morality and the decision lies with the individual not the law. ${ }^{23}$

It could be argued that it is unfair that a perfectly able person could commit suicide and not be punished for it. Whereas when someone wants to die because of their suffering from an incurable illness they are unable to do so as they do not have the ability to do it themselves. ${ }^{24}$ A modern liberal state in the eyes of someone like Mill should provide a law that is equal to all. This would mean that all individuals would have this right to exit life, provided the law was protected from abuse. ${ }^{25}$ If we are judging the ethical tone of society by the way we treat the most vulnerable then the state actually puts them at a disadvantage and it is unfair that they are not provided with the same options as a physically able person.

\footnotetext{
${ }^{20}$ Ibid

${ }^{21}$ Margaret Somerville 'Legalising assisted dying would be a failure of collective human memory and imagination', The Guardian (2017) $<$ https://www.theguardian.com/commentisfree/2017/sep/20/legalising-assisted-dying-wouldbe-a-failure-of-collective-human-memory-and-imagination> accessed 23 March 2018

${ }^{22}$ Eilionóir Flynn and Anna Arstein-Kerslake 'State intervention in the lives of people with disabilities: The case for a disability-neutral framework’ (2017) 13(1) International Journal of Law in Context, 54

${ }^{23}$ Ibid

${ }^{24}$ Nigel Warbuton 'Suicide is legal - why are those who need assistance denied this right?', The Guardian (2014) <https://www.theguardian.com/commentisfree/2014/jun/26/suicidelegal-assistance-kill-themselves> accessed 30th March 2018 ${ }^{25}$ Ibid
} 
A statistic that is thought to cause alarm in the article is that only ' $5 \%$ of people mention pain as a reason for wanting euthanasia, around $48 \%$ of people give feeling like a burden on others ${ }^{26}$. Mill, however, did address the limits of his principle. He states that 'those who are still in a state to require being taken care of by others must be protected against their own actions as well as external injury. ${ }^{, 7}$ Somerville's article echoes this by stating in other countries euthanasia is 'now available to children, newborn babies with serious disabilities an people with dementia and mental illness... euthanasia puts the lives of individuals, especially vulnerable people, such as those with disabilities, at risk.' ${ }^{28}$ Mill did appreciate that those who have not achieved autonomy can be interfered with. ${ }^{29}$ This would imply that if euthanasia and assisted dying were to be legalised safeguards would need to be put in place to protect those who have not achieved autonomy and are influenced by the wishes or pressures of others. These safeguards could include the fact the patient must be an adult and they must also be mentally competent when making the decision. ${ }^{30}$ Following the harm principle the $5 \%$ of people who want to die to relieve their pain should be allowed to do so as not allowing them to die is restricting their liberty. They should be allowed to take responsibility for their own lives as long as they cause no harm to others. ${ }^{31}$ Whereas it could be argued that the $48 \%$ have not achieved autonomy and restraints are justified to protect them. ${ }^{32}$ Euthanasia and assisted suicide should be there for an option for those who need it to achieve their liberty.

However Somerville's article argues that 'once euthanasia becomes normalised slippery slopes are unavoidable and the number of deaths resulting from euthanasia

\footnotetext{
${ }^{26}$ Margaret Somerville 'Legalising assisted dying would be a failure of collective human memory and imagination', The Guardian (2017) $<$ https://www.theguardian.com/commentisfree/2017/sep/20/legalising-assisted-dying-wouldbe-a-failure-of-collective-human-memory-and-imagination> accessed 23 March 2018

${ }^{27}$ John Stuart Mill, On Liberty ( ${ }^{\text {nd }}$ edn, London: John W Parker \& Son West Strand 1859) $22-$ 23

${ }^{28}$ Margaret Somerville 'Legalising assisted dying would be a failure of collective human memory and imagination', The Guardian (2017) $<$ https://www.theguardian.com/commentisfree/2017/sep/20/legalising-assisted-dying-wouldbe-a-failure-of-collective-human-memory-and-imagination> accessed 21 March 2018 ${ }^{29}$ John Stuart Mill, On Liberty (2nd edn, London: John W Parker \& Son West Strand 1859) 30 Joe Public Bloggs 'Assisted Dying', The Guardian (2009) $<$ https://www.theguardian.com/society/joepublic/2009/jul/01/euthanasia-assisted-suicide-uk> accessed 27th March 2018

${ }^{31}$ John Stuart Mill, On Liberty ( $2^{\text {nd }}$ edn, London: John W Parker \& Son West Strand 1859)

${ }^{32}$ Ibid
} 
constantly substantially increases. ${ }^{33}$ This argument propels that voluntary euthanasia will lead to involuntary euthanasia. Those who feel they are not valuable to society or are vulnerable to abuse will feel there is no other option and legalising voluntary euthanasia opens them up to this risk. ${ }^{34}$ However euthanasia and assisted suicide cannot be refused just because of a mere possibility. If that were the case it would be fair to address the same slippery slope argument to ensure a dignified death of a competent individual. ${ }^{35}$ It must be taken into consideration how likely this is to happen. Somerville notes that 'opponents of voluntary euthanasia on slippery slope grounds have not provided the data or evidence necessary to turn their speculative concerns into wellgrounded likelihoods. ${ }^{36}$ It would be unfair on the grounds of a mere possibility to restrict competent individuals from achieving liberty by seeking assisted suicide or euthanasia, they should be allowed to do as they wish as long as it causes no harm to anyone else.

One of the messages of Somerville's article is that euthanasia and assisted suicide provide a depersonalised and dehumanised death. ${ }^{37}$ There have been cases where individuals have fought for their liberty and their right to die in a more humane way then the suffering they are going through. ${ }^{38}$ In the case of Pretty $v$ United Kingdom Mrs Diane Pretty suffered from motor neurone dieses and was paralysed. She wanted to ensure that if her husband accompanied her to seek assisted suicide he would not be prosecuted. Mrs Pretty wanted to be in control of when and how she died and wanted to be spared the suffering and indignity of the disease. However Mrs Pretty was denied this. ${ }^{39}$ Despite Somerville's concern for death being dehumanised and depersonalised, it would appear that refusing to allow Mrs Pretty to seek assisted suicide resulted in

\footnotetext{
${ }^{33}$ Margaret Somerville 'Legalising assisted dying would be a failure of collective human memory and imagination', The Guardian (2017) $<$ https://www.theguardian.com/commentisfree/2017/sep/20/legalising-assisted-dying-wouldbe-a-failure-of-collective-human-memory-and-imagination> accessed 24 March 2018

${ }^{34}$ Ellen Verbakel and Eva Jaspers'A Comparative study on permissiveness toward Euthanasia: Religiosity, slippery slope, Autonomy, and Death with Dignity’ (2010) 74(1) The Public Opinion Quarterly, 113

${ }^{35}$ Dan W Brock 'Voluntary Active Euthanasia' (1992) 22(2) The Hastings Center Report, 19

${ }^{36}$ Ibid page 20

${ }^{37}$ Margaret Somerville 'Legalising assisted dying would be a failure of collective human memory and imagination', The Guardian (2017) $<$ https://www.theguardian.com/commentisfree/2017/sep/20/legalising-assisted-dying-wouldbe-a-failure-of-collective-human-memory-and-imagination> accessed 24th March 2018

${ }^{38}$ Pretty v United Kingdom (App no 2346/02) - [2002] ECHR 2346/02

${ }^{39}$ Ibid
} 
Mrs Pretty suffering more and her death was less dignified. If the courts were to follow the approach of the harm principle then Mrs Pretty would have been able to achieve her wishes and avoid a situation that caused her and her family great stress. ${ }^{40}$ Mrs Pretty's autonomy was taken away from her, something the harm principle greatly condemns. It is situations like this where refusing assisted suicide actually causes more pain and suffering then allowing it ever would.

It is clear there is ambiguity with the global views of whether or not assisted suicide and euthanasia should be illegal, it is now legal in places like the Netherlands and Belgium. ${ }^{41}$ UK citizens can travel abroad to a jurisdiction where it is legal to seek an end to their life. However normally due to illness like in Mrs Pretty's case the issue is getting there and family members like Mrs Pretty's husband are put in an awful position of facing the crime of assisting suicide if they help. ${ }^{42}$ Despite this predicament 'one in five people who travel to Switzerland to end their lives are from the UK.' ${ }^{43}$ This shows how individuals are getting around the state restrictions imposed on them to achieve individual liberty anyways. This predicament indicates that if the Government want to be in more control they should legalise euthanasia and assisted suicide and govern it themselves, rather than allowing other jurisdictions to give individuals that option and taking it away from those who simply can not travel. If they were to govern this area in a way that is less restrictive to autonomy then members of the UK would not feel the need to travel abroad to achieve freedom. ${ }^{44}$

\section{Criticism of the harm principle}

However despite the harm principle's main aim being to protect a person's liberty and reduce state intervention, its approach does not come without criticism.. One of the biggest criticisms of the harm principle is that Mill is not clear on what is actually meant

\footnotetext{
${ }^{40}$ Ibid

${ }^{41}$ Margaret Somerville 'Legalising assisted dying would be a failure of collective human memory and imagination', The Guardian (2017) $<\underline{\text { https://www.theguardian.com/commentisfree/2017/sep/20/legalising-assisted-dying-would- }}$ be-a-failure-of-collective-human-memory-and-imagination> accessed 24 March 2018

42 Pretty v United Kingdom (App no 2346/02) - [2002] ECHR 2346/02

${ }^{43}$ Haroon Siddique 'One in five visitors to Swiss assisted-dying clinics from Britain', The Guardian (2014) <https://www.theguardian.com/society/2014/aug/20/one-in-five-visitorsswiss-suicide-clinics-britain-uk-germany> accessed 26th March 2018

44 Joe Public Bloggs 'Assisted Dying', The Guardian (2009) $<$ https://www.theguardian.com/society/joepublic/2009/jul/01/euthanasia-assisted-suicide-uk> accessed 26th March 2018
} 
by harm or what acts are to be prescribed. ${ }^{45}$ At the core of the principle, harm has to be thought of as anything that interferes with a person's autonomy. ${ }^{46}$ Mill did make a distinction between self-regarding actions that are those that affect only yourself and other regarding actions that are those that affect others. ${ }^{47}$ However almost any actions could be said to have a negative consequence on others so in that aspect the harm principle fails as a protection mechanism against state instruction. ${ }^{48}$ Some scholars would argue that it is this regular reference to indirect harm that has caused the harm principle to somewhat collapse. ${ }^{49}$ Mill did consider harm to 'certain interests which either by express provision or tacit understanding, ought to be considered as rights, 50 as constituting harm. It could be argued that euthanasia and assisted suicide inflict indirect harm upon the individual's friends and family. However Mill did appreciate that if it does affect 'others, only with their free, voluntary and undeceived consent and participation.' ${ }^{51}$ It was clear when looking at the Pretty case that her family were supportive of her choice. ${ }^{52}$ When those around have voluntarily consented to the indirect harm there should be even less reason to restrict someone. When it is clear that no harm is caused the principle should be applied. Reference to possible clarification on what can be classed as harm is discussed below.

Another common critique of the harm principle is that it is too permissive. It is instrumental to a permissive society where an individual can do things others disapprove of. ${ }^{53}$ Lord Patrick Devlin would also seem to disagree with the elements behind the harm principle and believe it makes society too permissive. His thoughts are basically that criminal law is to protect society as well as the individual and should not be limited to acts that cause harm to another individual. ${ }^{54}$ Following the article discussed above a point is raised that euthanasia and assisted suicide should not be

\footnotetext{
${ }^{45}$ John P Safranek, ‘Autonomy and Assisted Suicide The Execution of Freedom', (1998) 28(4) Hastings Center Report 28, 33

${ }^{46}$ John Stuart Mill, On Liberty ( ${ }^{\text {nd }}$ edn, London: John W Parker \& Son West Strand 1859) 134

${ }^{47}$ John Stuart Mill, On Liberty ( ${ }^{\text {nd }}$ edn, London: John W Parker \& Son West Strand 1859)

${ }^{48}$ Piers Norris Turner, '”Harm” and Mill’s Harm Principle' (2014) 124(2)

${ }^{49}$ Bernard Harcourt 'The collapse of the Harm Principle' (1999) 90 Journal of Criminal Law and Criminology 109

${ }^{50}$ John Stuart Mill, On Liberty ( $2^{\text {nd }}$ edn, London: John W Parker \& Son West Strand 1859) 134

${ }^{51}$ John Stuart Mill, On Liberty (2nd edn, London: John W Parker \& Son West Strand 1859) 26

${ }^{52}$ Pretty v United Kingdom (App no 2346/02) - [2002] ECHR 2346/02

${ }^{53}$ Daniel Jacobson 'Mill on Liberty, Speech, and the Free Society' (2000) 29(3)Philosophy \& Public Affairs, 278

${ }^{54}$ Peter Cane 'Taking Law Seriously: Starting Point of the Hart/Devlin debate' (2006) 10(1) the Journal of Ethics, 22
} 
legalised because of the potential damage to the ethical tones of society ${ }^{55}$, Lord Devlin would seem to agree with this. Devlin believes it is an offence against society to threaten the social cohesion made possible by the common view on morality. ${ }^{56}$ As there are those who strongly oppose euthanasia and assisted suicide, Lord Devlin would seem to believe that it should remain illegal on grounds of social morality.

However Herbert Hart famously disagrees with Lord Devlin. He states 'to punish people for causing this form of distress would be tantamount to punishing them simply because others object to what they do and the only liberty that could coexist with this... is the liberty to do things to which no one seriously objects. ${ }^{57}$ The critics of Mill seem to think it is justifiable to punish departures from social morality even if it does not cause harm to others. ${ }^{58}$ But Hart appreciates on the 'narrower issue relevant to the enforcement of morality Mill seems to be right. ${ }^{59}$ While Hart is a liberal like Mill he is a different kind of liberal. Hart can be described as a Paternalistic Millsian. ${ }^{60} \mathrm{He}$ 'suggests a modified principle of liberty which accommodates paternalism by protecting consenting victims without condoning the legal moralism of Devlin. ${ }^{61}$ Hart acknowledges that the law should protect individuals from physically harming themselves. ${ }^{62}$ Mill's view is that neither physical or moral grounds are acceptable for state intervention. ${ }^{63}$ This would indicate that despite generally agreeing with Mill, Hart would be opposed to legalising euthanasia and assisted suicide. It would indicate that legal coercion in these circumstances is justified. ${ }^{64}$

\footnotetext{
${ }^{55}$ Margaret Somerville 'Legalising assisted dying would be a failure of collective human memory and imagination', The Guardian (2017) $<$ https://www.theguardian.com/commentisfree/2017/sep/20/legalising-assisted-dying-wouldbe-a-failure-of-collective-human-memory-and-imagination> accessed 24th March 2018

${ }^{56}$ Robert P George 'Social Cohesion and the Legal Enforcement of Morals: A Reconsideration of the Hart-Devlin Debate' (1990) 35 American Journal of Jurisprudence, 19

${ }^{57}$ H.L.A Hart, Law, Liberty and Morality (Stanford University Press 1963) 47

${ }^{58}$ Ibid, 5

${ }^{59}$ Ibid, 5

${ }^{60}$ Christine Pierce 'Hart on Paternalism' (1975) 35(6) Analysis, 205

${ }^{61}$ Ibid, 205

${ }^{62}$ Raymond Wacks, Understanding Jurisprudence an Introduction to Legal theory $3^{\text {rd }}$ edn Oxford University Press 2012) 36

${ }^{63}$ John Stuart Mill, On Liberty (2 ${ }^{\text {nd }}$ edn, London: John W Parker \& Son West Strand 1859) 22

${ }^{64}$ H.L.A Hart, Law, Liberty and Morality (Stanford University Press 1963) 5
} 


\section{Support for the harm principle}

Despite the criticisms of the harm principle discussed above, there is strong evidence to indicate Mill's harm principle is still fundamental to what a liberal society is perceived to be. In the judgment of $R v$ Brown the judges considered Mill's harm principle in their judgment to conclude that the sado-masochistic group should be free to pursue their own vision, if they are not free to pursue it their autonomy is being prevented. ${ }^{65}$ This is also a common critique on the illegality of euthanasia, that it violates an individual's autonomy. ${ }^{66}$ Central to Mill's interpretation on freedom is the necessity of autonomy and how an individual should be free to take responsibility of their own lives as long as they cause no harm to others. ${ }^{67}$ It is an indefensible encroachment upon an individual's liberty to stop a competent terminally ill person from seeking assisted suicide. The desire to end life with dignity comes from a right to individual autonomy. ${ }^{68}$

The Wolfenden Report also valued individual autonomy when stating 'there must be a realm of private morality and immorality which is, in brief and crude terms, not the law's business. ${ }^{69}$ This reflects the view of the harm principle that in private people should be able to pursue private acts that are not harmful to others. It does not matter if others disapprove of it, are offended by it or find it immoral. ${ }^{70}$ Herbert Hart pointed out that the foundation of this report had striking similarities to Mill's harm principle. ${ }^{71}$ Although the Wolfenden Report was with regards to homosexuality and prostitution these points could also be regarded for euthanasia and assisted suicide. It is up to the individual to decide what is moral in his private life and hence when to end his life. Looking at this view from 'a liberal society based on the principle of moral autonomy of the individual the law should not be concerned with preventing people

\footnotetext{
${ }^{65} \mathrm{R}$ v Brown [1994] 1 A.C. 212

${ }^{66}$ John P Safranek, ‘Autonomy and Assisted Suicide The Execution of Freedom', (1998) 28(4)

Hastings Center Report 28, 32

${ }^{67}$ Bruce Baum 'J. S. Mill on Freedom and Power' (1998) 31(2) Polity, 187

${ }^{68}$ Mirko Bagaric 'Euthanasia: Patient Autonomy Versus the Public Good' (1999) 18(1)

University of Tasmania Law Review, 152

${ }^{69}$ The Report of the Committee on Homosexual Offences and Prostitution, Cmnd 247, HMSO, 1957 ('Wolfenden Report')

${ }^{70}$ Christine Pierce 'Hart on Paternalism' (1975) 35(6) Analysis, 205

${ }^{71}$ H.L.A Hart, Law, Liberty and Morality (Stanford University Press 1963) 14
} 
from taking their lives'. ${ }^{72}$ For the law to intervene it would have to show that suicide involved direct harm to others. ${ }^{73}$ The aim of authorised state intervention should not be to restrict the individual's liberty or force protection on them it should be only to provide support in the individuals circumstances. ${ }^{74}$

\section{Conclusion}

Mill predicted that his work On Liberty would last longer then anything he has ever written and he was right. ${ }^{75}$ It is clear his harm principle is still central to modern day debate. It would appear that the foundations of the harm principle would support legalising euthanasia and assisted suicide. An individual should be allowed to make their own choices regarding their private life and death is a very personal. For the state to intervene and take this away from an individual is infringing on their autonomy, something Mill was very clear is essential to an individual's liberty. It is also very unfair that an individual is put at a legal disadvantage simply for not being able to physically commit suicide on their own, the law should be equal for all. Somerville's article raises some valuable points and it is easy to see why there are concerns, however, as long as the new law would be adapted to protect those who have not yet achieved autonomy there is no issue with making it an option for those who have. After all 'over himself, over his own body and mind, the individual is sovereign. ${ }^{76}$

\footnotetext{
${ }^{72}$ Max Charlesworth, Bioethics in a Liberal Society (Cambridge: Cambridge University Press 1993) 39

${ }^{73}$ Ibid

${ }^{74}$ Eilionóir Flynn and Anna Arstein-Kerslake 'State intervention in the lives of people with disabilities: The case for a disability-neutral framework’ (2017) 13(1) International Journal of Law in Context, 54

${ }^{75}$ John Stuart Mill, On Liberty ( $2^{\text {nd }}$ edn, London: John W Parker \& Son West Strand 1859)

${ }^{76}$ John Stuart Mill, On Liberty ( ${ }^{\text {nd }}$ edn, London: John W Parker \& Son West Strand 1859)
} 